\title{
Coil Embolization of Intracranial Aneurysms with Ipsilateral Carotid Stenosis: Technical Considerations
}

\author{
Ípsilateral Karotid Stenoz Bulunan Intrakraniyal Anevrizmalarn \\ Koil Embolizasyonu:Teknik Hususlar
}

Vipul GUPTA ${ }^{1}$, Swati CHINCHURE ${ }^{1}$, Gaurav GOEL ${ }^{1}$, Ajaya Nand JHA², Aditya GUPTA², Karanjit Sing NARANG ${ }^{2}$

${ }_{1}^{1}$ Medanta, The Medicity, Interventional Neuroradiology. Institute of Neurosciences, Gurgaon, India

${ }^{2}$ Medanta, The Medicity, Department of Neurosurgery, Gurgaon, India

Corresponding Author: Swati CHINCHURE / E-mail: swatichinchure@yahoo.com

\begin{abstract}
Simultaneous occurrence of carotid atherosclerotic disease and ipsilateral cerebral aneurysm is known because of common risk factors. When interventional neuroradiologists encounter such cases, issue of 'in which order to treat these lesions' is raised. If carotid artery disease is treated first, then acute increase in perfusion pressure and high dose antiplatelets might increase the risk of aneurysm rupture. If aneurysm coiling is performed first, the stroke risk may increase due to manipulations through plaque and compromise of cerebral flow secondary to catheter placement through stenotic vessel. Even though aneurysm coiling first is a rational approach, there are technical problems like crossing the carotid lesion safely and making sure that placement of catheter through the stenosed vessel will not compromise the cerebral blood flow. This technical report describes our protocol in performing safe and successful coil embolization in three cases with moderate carotid stenosis and ipsilateral intracranial aneurysm. Our emphasis is mainly on technical considerations with the aim of avoiding cerebral embolism during crossing of carotid plaque and to avoid compromise of cerebral blood flow using 'syngo iflow'. These technical considerations may have important implications in treatment of intracranial aneurysm in patients with moderate ipsilateral cervical carotid stenosis.
\end{abstract}

KEYWORDS: Carotid stenosis, Ipsilateral intracranial aneurysm, Syngo iflow, coiling

öz

Karotid aterosklerotik hastalık ve ipsilateral serebral anevrizmanın eşzamanlı oluşumu, ortak risk faktörleri nedeniyle bilinmektedir. Girişimsel nöroradyologlar bu gibi durumlarda karşılaştığında, 'bu lezyonların hangi sırayla tedavi edileceği' sorunu ortaya çıkar. Karotis arter hastalığı önce tedavi edilirse, perfüzyon basıncında akut artış ve yüksek doz antitrombositler anevrizma rüptürü riskini artırabilir. Eğer önce anevrizmaya koil konursa, plak içinden manipülasyonlar ve stenotik damar yoluyla kateter yerleştirmeye sekonder olarak serebral akışın olumsuz etkilenmesi nedeniyle inme riski artabilir. Illk önce anevrizmaya koil konması akılcı bir yaklaşım olsa da karotis lezyonunu güvenli şekilde geçmek ve kateteri daralmış damar yoluyla yerleştirmenin serebral kan akışını tehlikeye atmayacağından emin olmak gibi teknik sorunları vardır. Bu teknik rapor, orta derecede karotis darlığı ve ipsilateral intrakraniyal anevrizması olan üç olguda güvenli ve başarılı bir koil embolizasyonu uygulama protokolümüzü açıklamaktadır. Temel olarak karotis plak geçişi sırasında serebral emboliden kaçınmak ve 'syngo iFlow' kullanarak serebral kan akımının olumsuz etkilenmesini önlemek amacıyla teknik hususları vurgulamaktayız. Bu teknik hususlar orta derecede ipsilateral servikal karotis darlığı olan hastalarda intrakraniyal anevrizma tedavisinde önemli olabilir.

ANAHTAR SÖZCÜKLER: Karotid darlığı, İpsilateral intrakraniyal anevrizma, Syngo iflow, Koil yerleştirme

\section{INTRODUCTION}

The incidence of simultaneous occurrence of cervical carotid stenosis and intracranial aneurysms is approximately $3 \%$ (8). This might be because of common risk factors shared by carotid atherosclerotic disease and cerebral aneurysms like advancing age, tobacco use and hypertension (12). Such combinations of cervical carotid disease and ipsilateral intracranial aneurysms complicate the management of either disease. Relief of the carotid stenosis, leading to a sudden rise in intracranial perfusion altering intracranial hemodynamics plus subsequent high dose antiplatelets might increase the potential risk of aneurysm rupture $(2,14,9)$. Conversely, repair of aneurysms with the patients under general anesthesia may increase the risk of stroke because of decreased cerebral blood flow (CBF) imposed by the carotid stenosis $(8,9)$ and placement of guiding catheter in the residual lumen. Even though aneurysm coiling first is a rational approach, there are technical problems concerning how to embolize the aneurysms through the cervical carotid stenosis.

Till date, various strategies for managing these group of patients have been advised in literature like repairing the intracranial aneurysm before performing carotid angioplasty/ 
endarterectomy $(6,14)$ performing both the procedures in the same sitting (17) and performing carotid angioplasty/ endarterectomy without repairing the intracranial aneurysm $(7,9,13)$ However there are no reports of coiling of aneurysm in patient with significant stenosis without treating the parent vessel carotid origin stenosis. We hereby report three cases of cerebral aneurysm with ipsilateral cervical carotid stenosis in whom successful embolization of aneurysm was done safely without carotid revascularization before or at the time of the embolization. In this article we describe the technical considerations during the procedure to avoid possible embolism or hemodynamic compromise due to catheter systems crossing the stenotic segment.

\section{CASES}

The demographic and angiographic characteristics of the patients are summarized in Table I.

\section{Case I}

A 56-year-old man, known hypertensive and diabetic, presented with right hand weakness that improved partially over next few hours. MRI showed few patchy infarcts in left middle cerebral artery (MCA) territory. MR angiography revealed approximately $70 \%$ stenosis at origin of left internal carotid artery ( ICA) along with an aneurysm at the anterior communicating artery (ACOM). Digital subtraction angiogram (Axiom Artis Zee; Siemens, Erlangen, Germany) along with 3D angiography were performed. Cerebral angiogram showed a left proximal ICA ulcerated plaque causing $50 \%$ stenosis (Figure 1A, B). Diffuse atherosclerotic changes seen with $50 \%$ stenosis in left MCA as well. A lobulated ACOM aneurysm measuring $6.7 \times 3.5 \times 4.4 \mathrm{~mm}$ (Figure $1 \mathrm{C}$ ) along with an outpouching from the fundus of the aneurysm. In view of borderline carotid stenosis with diffuse atherosclerotic changes, medical management was planned for ischemic symptoms. For unruptured anterior communicating artery aneurysm, the patient was given options of surgical, endovascular or conservative approach and he opted for endovascular management. The procedure was done under general anesthesia. After securing arterial access, he was

Table I: Demographic and Angiographic Data

\begin{tabular}{|c|c|c|c|c|c|c|c|c|c|}
\hline Age & Sex & $\begin{array}{l}\text { Stenosis } \\
\text { Location }\end{array}$ & $\begin{array}{l}\text { Stenosis } \\
\text { Severity }\end{array}$ & $\begin{array}{c}\text { Aneurysm } \\
\text { Size }\end{array}$ & $\begin{array}{l}\text { Aneurysm } \\
\text { Location }\end{array}$ & $\begin{array}{l}\text { Presenting } \\
\text { Symptoms }\end{array}$ & $\begin{array}{l}\text { AV Time- } \\
\text { Catheter } \\
\text { Proximal to } \\
\text { Stenosis }\end{array}$ & $\begin{array}{l}\text { AV time- } \\
\text { Catheter } \\
\text { Distal to } \\
\text { Stenosis }\end{array}$ & Complication \\
\hline 56 & $M$ & $\begin{array}{c}\text { Left } \\
\text { cervical } \\
\text { ICA }\end{array}$ & $50.00 \%$ & $\begin{array}{c}6.7 \times 3.5 \times 4.4 \\
\mathrm{~mm}\end{array}$ & ACOM & $\begin{array}{c}\text { Left MCA } \\
\text { patchy } \\
\text { infarcts }\end{array}$ & $5.8 \mathrm{sec}$ & $6.8 \mathrm{sec}$ & No \\
\hline 70 & $\mathrm{~F}$ & $\begin{array}{l}\text { Right } \\
\text { cervical } \\
\text { ICA }\end{array}$ & $50.00 \%$ & $\begin{array}{c}6.2 \times 4.8 \times 4.6 \\
\mathrm{~mm}\end{array}$ & $\begin{array}{l}\text { Right MCA } \\
\text { bifurcation }\end{array}$ & SAH & $4.8 \mathrm{sec}$ & $5.9 \mathrm{sec}$ & No \\
\hline 65 & M & $\begin{array}{c}\text { Right } \\
\text { cervical } \\
\text { ICA }\end{array}$ & $60.00 \%$ & $\begin{array}{c}4.7 \times 5.7 \times 6.3 \\
\mathrm{~mm}\end{array}$ & ACOM & $\begin{array}{c}\text { Headaches, } \\
\text { CAD }\end{array}$ & $5.8 \mathrm{sec}$ & $6.3 \mathrm{sec}$ & No \\
\hline
\end{tabular}

given a loading dose of 5000 units of heparin and thereafter hourly infusion of 1000 units. Cerebral angiogram including $3 \mathrm{D}$ angiogram was obtained with guiding catheter (5F, Envoy, Codman Neurovascular, Raynham, MA) tip proximal to the carotid lesion. Thereafter the stenotic segment was crossed with 0.014 " soft tip microguidewire (Transcend-14, Boston Scientific, Target Therapeutics, Fremont, CA) under biplane roadmap guidance, avoiding any undue manipulation of the carotid plaque. The tip of the guide wire was kept in the petrous segment of the left ICA. Then the Maverick PTCA balloon catheter (Boston Scientific, Target Therapeutics, Ireland) was placed over the wire under roadmap guidance into the petrous ICA. Thereafter the guiding catheter was navigated over the balloon catheter under roadmap guidance to the upper cervical ICA (Figure 1D,E). Cerebral angiogram was repeated in AP and lateral planes and the arterio-venous perfusion period was compared to the previous injection performed below the stenosis. For further evaluation, the "syngo iFlow" was used. Using this technique, the arteriovenous transition period is evaluated before and after crossing the lesion with a guiding catheter. It was confirmed that there is no perfusion delay after placing the guiding catheter (Figure $2 \mathrm{~A}, \mathrm{~B}$ ) beyond the carotid stenosis. Thereafter, coiling was performed successfully (Figure 1F). The patient made an uneventful recovery.

\section{Case II}

A 70-year-old lady, known hypertensive, presented with acute onset severe headache. CT scan revealed right Sylvian subarachnoid haemorrhage. Angiogram showed right MCA bifurcation aneurysm measuring approximately $6.2 \mathrm{~mm} x$ $4.8 \mathrm{~mm} \times 4.6 \mathrm{~mm}$ with a neck of $3.7 \mathrm{~mm}$. There was ulcerated plaque at ICA origin with approximately $50 \%$ stenosis. It was decided to embolize the aneurysm. The carotid lesion was asymptomatic and angioplasty would require anti-platelet therapy that was not considered to be desirable in view of the recent intracranial hemorrhage. The coiling procedure was performed with the technique as described except that antiplatelet drugs were not used in the peri-operative period. She made an uneventful recovery and was discharged on single anti-platelet medication. 

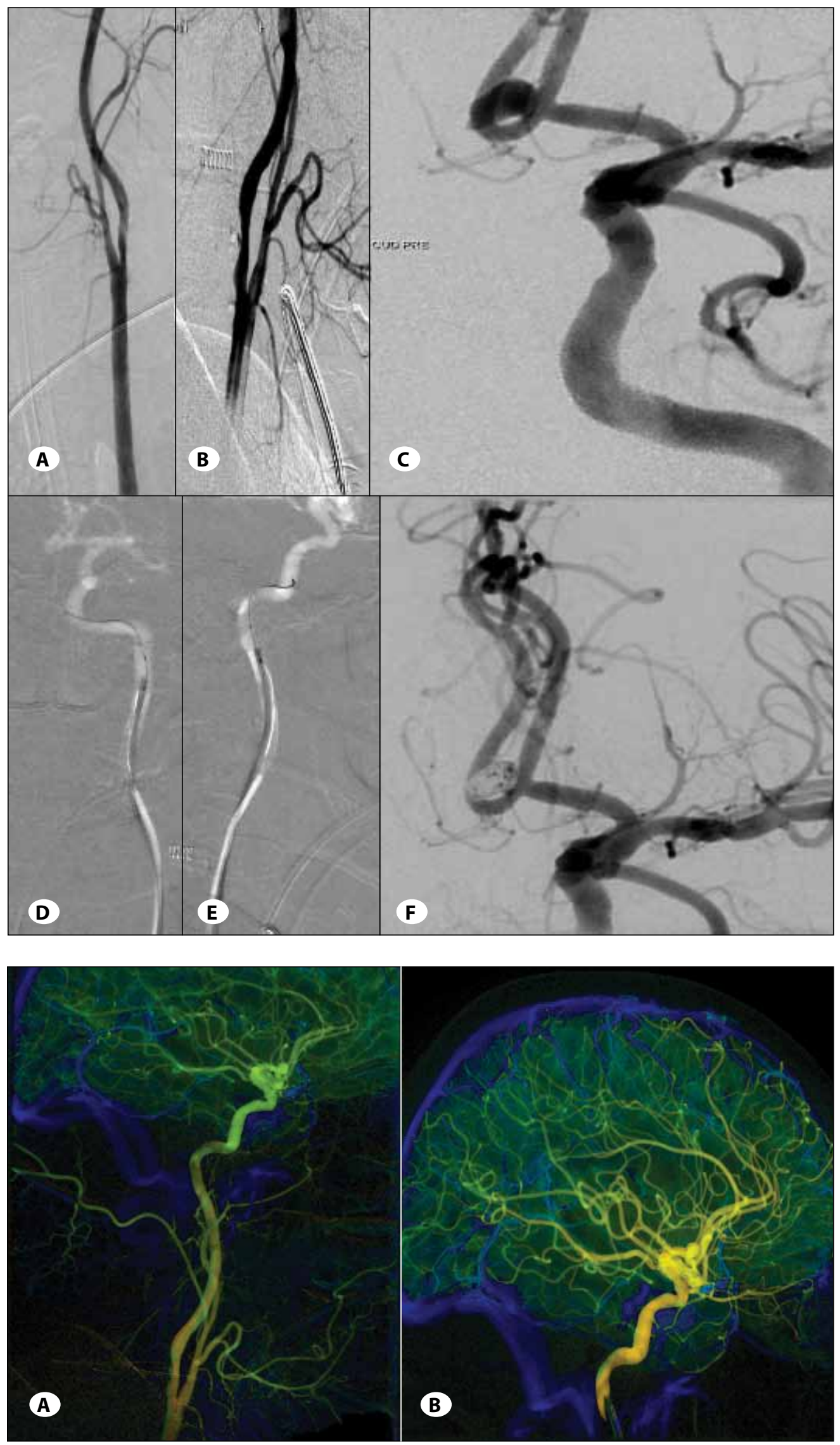

Figure 1: A, B) Cerebral angiogram showing left proximal ICA ulcerated plaque causing $50 \%$ stenosis. C) Angiographic projection showing lobulated ACOM aneurysm along with an outpouching from the fundus of the aneurysm. D,E) 5 French guiding catheter navigated across the ulcerared plaque over the completely deflated Maveric PTCA balloon catheter over 0.014 " microguidewire under biplane roadmap guidance to the upper cervical ICA. F) postembolization angiogram showing near complete aneurysm obliteration.

Figure 2: Cerebral Hemodynamic evaluation using "syngo iFlow". A) syngo iFlow colour-coded image of the angiogram obtained with guiding catheter placed proximal to the carotid stenosis and B) colour-coded image of the angiogram obtained with guiding catheter distal to the stenosis. Similar colour sheds in all of the intracranial vessels in these images suggest no significant change in cerebral blood flow after crossing the stenosis with guiding catheter. Note that the vein of Labbe in both the images shows the same blue color. 


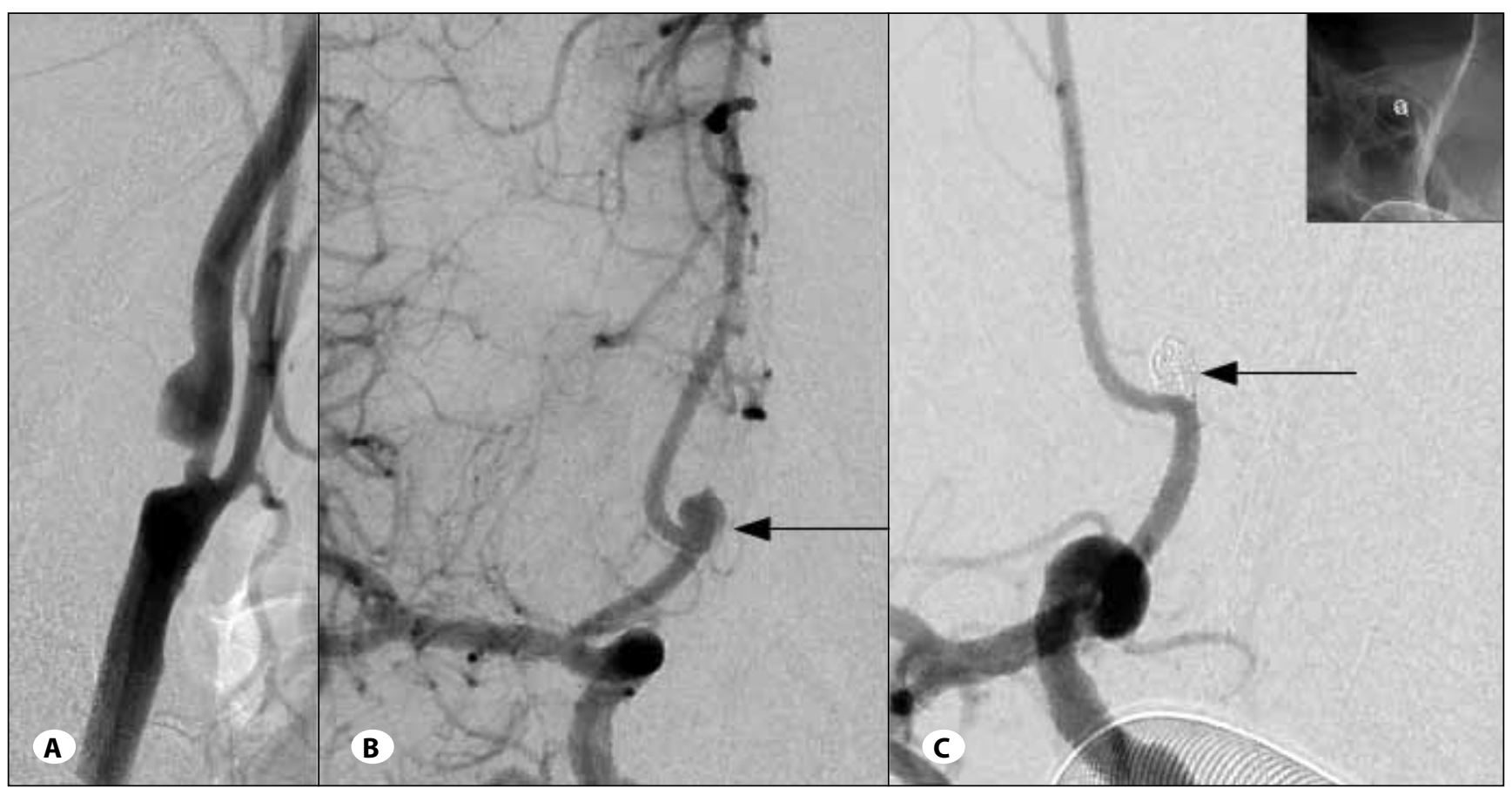

Figure 3: A) Angiogram showing 60\% stenosis of right ICA origin with an ulcerated plaque. B) Showing lobulated ACOM aneurysm with small superiorly pointing projection. C) Postembolization angiogram showing complete obliteration of the aneurysm.

\section{Case III}

A 65-year-old male patient with long-standing diabetes and hypertension was admitted for ischemic heart disease and scheduled for coronary artery bypass graft. On pre-surgical evaluation he was found to have incidental $60 \%$ stenosis of right ICA origin with an ulcerated plaque (Figure $3 \mathrm{~A}$ ) and an ACOM aneurysm measuring $4.7 \times 5.7 \times 6.3 \mathrm{~mm}$ (Figure 3B). He had a history of episodic headaches and the aneurysm had a projection from the fundus that was considered as a weak spot in aneurysm wall. It was decided to treat the aneurysm before coronary surgery. He was not given any anti-platelets in peri-operative period. The coiling and heparinization protocol was as described in first case. Complete occlusion of the aneurysm was achieved with no complications (Figure 3C) and the patient underwent uneventful bypass surgery after $a$ few days.

\section{DISCUSSION}

Occurrence of cerebral aneurysm ipsilateral to the carotid stenosis is usually an incidental finding. Of the 2885 patients participating in the North American Symptomatic Carotid Endarterectomy Trial (12), 51 (1.7\%) had ipsilateral unruptured intra-cranial aneurysms (8). There are reports of successful carotid endarterectomy without treatment of the intracranial aneurysm. Ladowski et al. (9) reported 19 such patients in whom carotid surgery was performed at 30day follow up no ruptures were recorded. Ballotta et al. (4) reported 11 patients with severe extracranial carotid stenosis and concomitant intracranial aneurysm who underwent carotid revascularization without aneurysm repair and on 5 years follow up, no patient developed SAH. However, in this study all the aneurysms were $<5 \mathrm{~mm}$. By analyzing the results of NASCET (12), Kappelle et al. (8) reported 25 patients with ipsilateral unruptured aneurysms who underwent carotid endarterectomy (CEA) on the side of their symptomatic artery without having them repaired. Subarachnoid hemorrhage occurred in 1 (4\%) of the 25 patients on the $6^{\text {th }}$ postoperative day. The patient died after 4 days of SAH. Adams HP (2) reported a case in which a patient with internal carotid stenosis and ipsilateral incidental ICA- posterior communicating artery junction aneurysm who was treated by surgical correction of carotid stenosis and later died of $\mathrm{SAH}$. Autopsy confirmed rupture of the aneurysm, that was previously visualized at angiography. Riphagen $\mathrm{JH}(16)$ also published on rupture of intracranial aneurysm after endarterectomy.

An aneurysm in the anterior circulation with severe ipsilateral carotid stenosis may be partially protected due to reduced blood flow and in turn reduced pressure in the head. Cronqvist and coauthors (5) have demonstrated that even partial carotid occlusion may lead to a reduction of aneurysm size. Recanalization of the carotid artery may increase the flow and in theory may increase the rupture risk (15). Therefore, once the decision has been made to treat a carotid artery stenosis, any distal aneurysms in its territory should also be secured (3)

With advancements in endovascular techniques, another approach has been simultaneous ipsilateral proximal carotid artery stenting and cerebral aneurysm coiling. Badruddin A et al. (3) described 10 such cases, with good clinical and anatomical results. There are few case reports 
of staged endovascular treatment of symptomatic carotid bifurcation stenosis and incidental cerebral aneurysm (6). The endovascular approach may become the desirable approach in view that the simultaneous treatment reduces the possible change in hemodynamics leading to growth or rupture of the aneurysm.

However, the literature regarding symptomatic aneurysm in presence of associated incidental carotid stenosis is more limited. In the series from Badruddin A et al. (3) there were two patients with SAH who were treated by simultaneous carotid stenting and coiling of aneurysm. However, this necessitated use of anti-platelets that may increase the risk of hemorrhagic complication in patients with recent aneurysm rupture. Patients with SAH may also need procedures such as ventricular drainage or surgery that may be complicated by the use of these drugs. In our small series we have tried to demonstrate feasibility of aneurysm coiling with coexistent moderate carotid stenosis without performing carotid revascularization. As in our cases, this approach may be useful particularly in patients when use of anti-platelet therapy is not desirable such as when the aneurysm is ruptured or when the patient has to undergo a major surgical procedure. Although surgical clipping is an option, we opted for endovascular coling in ruptured aneurysm as recent trials have demonstrated better clinical outcome in patients with ruptured aneurysms by endovascular methods as compared to surgical clipping [ISAT (11), BRAT (10)] On the other hand, neurosurgical clipping of the intracranial aneurysm with the patient under general anesthesia in patients with a carotid stenosis may increase the perioperative risk of ischemic stroke (6), particularly if hypotension is deliberately induced during the procedure. Our first patient was on antiplatelet therapy for ischemic symptoms and the third patient had underlying coronary artery disease, making surgery high risk in both.

The major risk of aneurysm coiling in presence of ipsilateral carotid stenosis is thrombo-embolism while crossing across the plaque. We crossed carotid lesions with a microguidewire $\left(0.014^{\prime \prime}\right)$ with a soft torquable soft tip instead of our usual practice of using a 0.035 or 0.038 " guidewire. Simultaneous biplane roadmap was used to cross the lesion so as to avoid any injury to the plaque. Thereafter a deflated coronary angioplasty balloon catheter was guided over the microguidewire to distal cervical ICA. These balloons have low profiles with smooth tapering tip and its placement was unlikely to cause plaque disruption while crossing the lesion. The micro-guidewire along with the balloon catheter provided good support to place the guiding catheter, similar or better support than the usual thicker guidewires. We also used a smaller profile guiding catheter (5F Envoy, Codman Neurovascular, Raynham, MA) instead of our usual practise of using a $6 \mathrm{~F}$ guiding catheter. Using this technique we were able to avoid any plaque injury along with a stable guiding system for embolization procedure.

Another possible issue in these cases was reduction of perfusion pressure and hemodynamic compromise because of guiding catheter placement across the stenotic segment. To evaluate for any hemodynamic change we compared the arterio-venous circulation time before and after crossing the stenosis. This was done by comparing the time interval between opacification of intracranial ICA to earliest appearance of fronto-parietal cortical vein. This assessment has been considered to be reliable in assessment of cerebral perfusion (1). The hemodynamic variables were further assessed with syngo iFlow (Siemens, Erlangen, Germany) technique. syngo iFlow is a single image that shows the history of the contrast media through the vessels in colour. This image provides ease of assessment of contrast flow within the parenchyma by showing a complete Digital Subtraction Angiography (DSA) run in a single image. In this image, the maximum opacification of each pixel is provided with a time from injection. This time is then represented by a color (ranging from red to blue) representing early, middle and late flow in the section of the DSA. In all of our cases there was no significant change in haemodynamics as evaluated by these techniques.

To conclude, we are reporting three cases with moderate grade carotid stenosis and ipsilateral intracranial aneurysms in which we could successfully and safely coil the aneurysm through carotid lesion using above described techniques. Using appropriate techniques we could avoid thrombo-embolism or hemodynamic compromise during the procedures. However, in view of the small number of cases, we need more data concerning the safety of the technique. Secondly, our technique is not feasible in very severe carotid stenosis in which stenting or angioplasty may be necessary to perform a coiling procedure. Another issue with our technique is that since we used a lower profile 5F guiding catheter, simultaneous placement of a balloon catheter would not have been possible as it requires minimum $6 \mathrm{~F}$ guiding catheter.

\section{REFERENCES}

1. Abud DG, Spelle L, Piotin M, Mounayer C, Vanzin JR, Moret $\mathrm{J}$ : Venous phase timing during balloon test occlusion as a criterion for permanent internal carotid artery sacrifice. Am J Neuroradiol 26(10): 2602-2609, 2005

2. Adams HP Jr: Carotid stenosis and coexisting ipsilateral intracranial aneurysm. A problem in management. Arch Neurol 34(8): 515-516, 1977

3. Badruddin A, Teleb MS, Abraham MG, Taqi MA, Zaidat OO: Safety and feasibility of simultaneous ipsilateral proximal carotid artery stenting and cerebral aneurysm coiling. Front Neurol 1: 120, 2010

4. Ballotta E, Da Giau G, Manara R, Baracchini C: Extracranial severe carotid stenosis and incidental intracranial aneurysms. Ann Vasc Surg 20 (1): 5-8,2006

5. Cronqvist S, Lundberg N, Troupp H: Temporary or incomplete occlusion of the carotid artery in the neck for the treatment of intracranial arterial aneurysms. Neurochirurgia 7:146-151, 1964 
6. Iwata T, Mori T, Tajiri H: Successful staged endovascular treatment of a symptomatic cervical carotid bifurcation stenosis coupled with a coincidental unruptured cerebral aneurysm in the carotid distal segment. Am J Neuroradiol 29: 1948-1950, 2008

7. Kann BR, Matsumoto T, Kerstein MD: Safety of carotid endarterectomy associated with small intracranial aneurysms. South Med J 90:1213-1216,1997

8. Kappelle LJ, Eliasziw M, Fox AJ, Barnett HJ: Small, unruptured intracranial aneurysms and management of symptomatic carotid artery stenosis. North American Symptomatic Carotid Endarterectomy Trial Group. Neurology 55(2): 307-309, 2000

9. Ladowski JS, Webster MW, Yonas HO, Steed DL: Carotid end arterectomy in patients with asymptomatic intracranial aneurysm. Ann Surg 200 (1): 70-73, 1984

10. McDougall CG, Spetzler RF, Zabramski JM, Partovi S, Hills NK, Nakaji P, Albuquerque FC:The Barrow ruptured aneurysm trial. J Neurosurg 116 (1):135-144, 2012

11. Molyneux AJ, Kerr RS, Yu LM, Sneade M, Yarnold JA, Sandercock P, International Subarachnoid Aneurysm Trial (ISAT) Collaborative Group.: International subarachnoid aneurysm trial (ISAT) of neurosurgical clipping versus endovascular coiling in 2143 patients with ruptured intracranial aneurysms: a randomised comparison of effects on survival, dependency, seizures, rebleeding, subgroups, and aneurysm occlusion. Lancet 366(9488):809-817, 2005
12. NASCET Trial Investigators: Clinical alert: Benefit of carotid endarterectomy for patients with high-grade stenosis of the internal carotid artery. National Institute of Neurological Disorders and Stroke and Trauma Division. North American Symptomatic Carotid Endarterectomy Trial (NASCET) investigators. Stroke 22 :816-817, 1991

13. Orecchia PM, Clagett PG, YoukeyJR, Brigham RA, Fisher DF, Fry RF, McDonald PT, Collins GJ, Rich NM: Management of patients with symptomatic extracranial carotid artery disease and incidental intracranial berry aneurysm. J Vasc Surg 2(1): 158-164, 1985.

14. Pappada G, Fiori L, Marina R, Vaiani S, Gaini SM: Management of symptomatic carotid stenoses with coincidental intracranial aneurysms. Acta Neurochir 138(12): 1386-1390, 1996

15. Pool JL, Putts DG: Aneurysms and arteriovenous anomalies of the Brain: Diagnosis and Treatment. New York: Harper \& Row, 1965: 417

16. Riphagen $\mathrm{JH}$, Bernsen $\mathrm{HJ}$ : Rupture of an intracerebral aneurysm after carotid endarterectomy: A case report. Acta Neurol Belg 109: 314-316,2009

17. Shumann MU, Mirzai S, Samii M, Vorkapic P: Xenon/CT CBF measurements as valuable diagnostic tool in a case of bilateral occlusive cerebrovascular disease associated with intracranial aneurysm. Acta Neurol Scand 166: 104-109,1996 